Journal Home Page:

http://perlinguam.journals.ac.za

\section{Per Linguam}

A Journal for Language Learning Tydskrif vir Taalaanleer

\title{
THE INFLUENCE OF AFFECTIVE VARIABLES ON THE ACQUISITION OF ACADEMIC LITERACY
}

\author{
Louise Olivier \\ Centre for Academic and Professional Language Practice, North-West University \\ Jako Olivier \\ School of Languages, North-West University
}

The teaching of academic literacy at university level, internationally and at universities in South Africa, is quite common. Despite a great deal of research on various facets of academic literacy, little research has been done in terms of the influence of attitudes, emotions and motivation as affective variables at the start of an academic literacy module. It is clear that societal and contextual factors have an influence on the emotions, motivation and attitudes of students. This article reports on open-ended questionnaires and a focus group interview conducted with students enrolled in an academic literacy module at the start of the module, as well as an open-ended questionnaire after the completion of the module. The initial phases of the research show students' negativity towards the module; however, after the completion of the module, students realise the value thereof. It is clear that within the context of the research populations in this study, more transparency is needed regarding the academic literacy test written prior to the start of the module, and students need to be better informed about the module so as not to only rely on peers' perceptions of the module. Furthermore, modules should be subject-specific rather than generic and relevant to the needs of the students.

\section{Keywords}

Academic literacy, compulsory courses, affective variables, positive psychology, peer influence, attitude, motivation, emotions, language testing, language learning, social constructivism, social learning theory

\section{INTRODUCTION}

Worldwide, many students do not acquire basic literacy at school level and continue to struggle at tertiary institutions (Hugo, 2003:48). Academic literacy courses provide a means through which literacy skills can be taught. As in any learning situation, certain affective variables can influence achievement (cf. Coles, 1999; Dehbozorgi, 2012:41; Noels, Pelletier $\&$ Vallerand, 2000:35). The main objective of this article is to determine the influence of emotions, motivation and attitudes as affective variables at the start of an academic literacy module.

Due to massification $^{1}$ in countries such as the UK, the USA, Australia, Canada and South Africa, the student profile has changed, resulting in a more varied student population. This change in student profile, together with the demands from future employers, forces 
universities to focus more on students' literacy levels, or, more specifically, lack thereof (Holder, Jones, Robinson \& Krass, 1999:19; Van Dyk, 2005:41; Van Schalkwyk, 2008:2). In South Africa there are countless students who have the intellectual ability to study at university level, but do not possess the required set of literacy skills to be academically successful (Hugo, 2003:48; Townsend, 2010:25; Weideman, 2007:xi). Hugo (2003:48) mentions that 'as far as South Africa is concerned there are many students studying at tertiary level whose levels of literacy including language abilities and reading abilities are not in line with the academic demands required by their studies.' According to Van Dyk (2005:45), 'about one third of first-year students at the Universities of North-West (Potchefstroom and Vaal Triangle campuses), Pretoria and Stellenbosch are at risk of not completing their studies in the prescribed time.' Weideman (2007:vi) states that 'language proficiency is an important predictor of learner success, albeit not the only one.' Poor language skills and knowledge, however, contribute to poor student performance (Weideman, 2006:82).

Therefore, for many students entering university, it can be a very daunting experience as they are expected to adopt and pick up 'university speak' (Van Schalkwyk, 2010:204) and are required to adhere to the conventions of the university's literacy requirements (Crouch, 2006). Many universities worldwide attempt to provide students with academic literacy courses to bridge the gap between high school and tertiary studies (Hugo, 2003:48; Skillen, 2006:140; Townsend, 2010:28). These academic literacy courses vary in nature, as they are based on various approaches to literacy and academic literacy.

At the North-West University (NWU) all first-year students write a compulsory academic literacy test (TAG/TALL) that establishes their level of academic literacy. The TAG (Toets van Akademiese Geletterdheidsvlakke) is used for students opting for Afrikaans and the TALL (Test of Academic Literacy Levels) is used for students with an English language preference (cf. ICELDA, 2013). Students below a cut-off point must complete an introductory generic, not a subject-specific, academic literacy module (AGLA111/AGLE111). However, all first-year students have to at least complete a compulsory generic academic literacy module (AGLA121, with Afrikaans as medium of instruction, or AGLE121, with English as medium of instruction). The AGLA121 module consists of three components, viz. a computer and information skills programme, a reading programme and an academic literacy lecture programme. The compulsory module focuses on core generic academic reading, writing, listening and seminar skills.

Despite the fact that students need academic literacy courses, some students do react negatively towards courses even before commencing their studies. It is proposed that due to socio-economic, affective factors and other people and issues influencing them, students do not always see the need for these courses and feel quite negative about them, which could result in them not acquiring the literacy skills expected from them at university level. Coles (1999) states that attention is not necessarily paid to the 'emotional side of literacy learning' in both literacy research and practice. Considering the large amount of research being done in South Africa on academic literacy (Carstens \& Fletcher, 2009; Crouch, 2006; Hugo, 2003; Van Dyk, 2005; Van Schalkwyk, 2008; Van Schalkwyk, 2010; Weideman, 2006; Weideman, 2007), it is evident that initial emotions, motivation and attitudes are not necessarily the focus of such studies. Consequently, this research will aim to explore these affective variables. 


\section{THEORETICAL FRAMEWORK}

\section{Academic literacy}

Traditionally, the 'autonomous' model of literacy was followed by many schools and universities, where literacy practices were seen as neutral, generic, technical or transferable (Kelder, 1996; Street, 2003; Picard, 2006:135) However, Street (2003) refers to a 'shift in approaches to literacy', where the ideological model is more favoured. In this article the ideological model is also followed and literacy is, hence, not regarded as a neutral technology (Street, 1984:28). In contrast to the autonomous model, Drackle (2006) mentions that 'with new literacy studies, on the other hand, literacy is looked upon as a social practice, dependent on context, on power relations, and on the relationships that people form with each other when literacy comes into play.' Therefore, it is important to look from a social point of view at peers as more knowledgeable others or 'more capable peers' (Vygotsky, 1978:86), and the environment also plays a role in students' attitudes, perceptions and ultimately motivation for the course (cf. Dörney \& Ushioda, 2010:29, 33-34). In this study, language acquisition, specifically academic literacy, will therefore be explored from within a social context within the ambit of the ideological model (Street, $1984 \& 2003$ ). Affective variables can be regarded as just as important as, if not more important than, aptitude in language learning and is discussed in the next section.

\section{Affective variables}

The main aim of this study is to explore the influence of affective variables on the acquisition of academic literacy. It is therefore important to consider literature relating to affective variables, especially in terms of language acquisition. The emphasis of affective variables on students ties in with the importance of a student or learner-centred approach in outcomesbased education (cf. Killen, 2000:xi). Dehbozorgi (2012:41) claims that the affective side of the learners is the most influential aspect in language learning success or failure. Noels et al. (2000:35) also emphasise the importance of affective variables. Research conducted on second language learning and acquisition is applicable in this context, as academic literacy can be seen as the acquisition of another language or 'discourse' (Gee, 1989).

Krashen (1981:21\&110) uses the term affective filter in terms of second language acquisition to refer to the condition in which attitudinal factors contribute to language learning. $\mathrm{He}$ (Krashen, 1981:21\&110) also he states that regardless of how teaching takes place, if the affective filter is up, no language acquisition will take place. Furthermore, Rubin and Thompson (1994:6) state that 'positive attitudes usually help learners to maintain their interest long enough to achieve language mastery.' Attitude affects levels of motivation and can make long-term differences in a student's academic career.

\section{Emotions and learning}

According to Hu, Real, Takamiya, Kang, Ledoux, Huganir and Malinow (2007:160), as well as Richter-Levin and Akirav (2003:248), the formation of memories and, by implication, learning is enhanced through emotional triggers. According to Coles (1999), to be able to understand the link between emotion and cognition, "the neural networks that integrate 
emotions and cognition' should also be considered, because at the neural level an emotional response can either contribute or hamper cognition and learning.

In addition, Pekrun, Goetz, Titz and Perry (2002:91\&103) also determined that 'academic emotions are significantly related to students' motivation.' Coles (1999) notes that emotions are linked to cognition. Not only does the experience of learning result in certain emotional responses, but the learning itself is also influenced by emotional states. As noted by Coles (1999), it is clear that to facilitate effective learning and teaching, positive emotions should be induced as much as possible.

Pekrun et al. (2002:91) observe that '[e]motions may trigger, sustain, or reduce academic motivation and related volitional processes.' Harlen and Crick (2003:173-174) state that '[m]otivational and emotional influences on learning: are affected by the learner's emotional state, beliefs, interests, goals and habits of thinking.' Therefore, it is important to consider motivation as an affective variable in terms of learning.

\section{Motivation and learning}

Keller (1983:389) defines motivation as 'choices people make as to what experiences or goals they will approach or avoid and the degree of effort they will exert in that respect.' In addition Dörney and Ushioda (2010:4) state that motivation is concerned with the direction and magnitude of human behaviour in terms of choice of action, persistence with this action and the effort expended on the action. However, motivation for learning is a complex concept influenced by a number of psychosocial factors (Harlen \& Crick, 2003:173).

Despite the fact that in cognitive theories of motivation the concept of motivation is viewed in the individual's cognitions and perceptions can be influenced by social and environmental factors (Dörney \& Ushioda, 2010:13, 25-26). It is evident from the literature that motivation is an important requirement for success in language learning (Brunton 2009:26; Dörney \& Ushioda, 2010:40-72).

The link between motivation and attitude has been identified by many studies (cf. Masgoret \& Gardner, 2003:124). For example, Brunton (2009:29) argues that attitude is a component of motivation and that in terms of language learning it is as important as aptitude. Krashen (1981:5) also believed that attitudinal and motivational factors are more important than aptitude.

\section{Attitudes and learning}

The link between motivation and attitude is clear from a definition of motivation by Gardner (1985:10) as "the combination of effort plus desire to achieve the goal of learning the language plus favourable attitudes toward learning the language." Masgoret and Gardner (2003:124) report on Gardner's socio-educational model of second language acquisition where two classes of attitudes, integrativeness and attitudes toward the learning situation, as well as motivation are distinguished. It is important to note that although both classes of attitudes are related to achievement "their effect is indirect, acting through motivation" (Masgoret \& Gardner, 2003:124). 
Individuals' attitudes are shaped through a socialisation process that includes the formation of values and beliefs. In the formation of attitudes, the modelling of others takes place in terms of experiences with people and in certain situations. A number of factors, including family, culture, religion and socioeconomic factors, can influence attitudes. The importance of attitudes can be traced to the fact that attitudes influence behaviour and what is remembered (cf. Pickens, 2005:48, 50). Dehbozorgi (2012:41) even notes that '[1]anguage attitude is believed to be the factor that makes differences between underachievement and accomplishment.' A number of studies support the idea that a student's attitude has an impact on the success of language learning (Gardner \& Lambert, 1972; Inal, Evin \& Saracaloglu, 2005:39), which is relevant because, as mentioned before, academic literacy can be considered as the acquisition of another language (Gee, 1989).

According to Pickens (2005:50), a person's attitude can be changed by addressing cognitive and emotional components. However, Pickens (2005:50) also states that such a change in attitude takes time, effort and determination.

From the overview, it is evident that a number, often interrelated, affective aspects such as emotions, motivation and attitudes influence language learning and acquisition. This blend of affective variables will be the focus of the empirical qualitative research done in this study as we try to gauge the influence of these variables on academic literacy acquisition.

\section{RESEARCH METHOD}

For the purpose of this study, a qualitative research design was decided upon. The intent of this study was not to measure attitude, emotions or motivation; rather an attempt was made to try to represent students' emotional experiences or their affect in its entirety, and to see and experience 'what they say their worlds are like' (Bruner, 1990:16).

The participant groups consisted of NWU students from the Faculty of Arts enrolled in the AGLA121 or AGLA111 modules. Informed consent was obtained from the participants to use their comments for research purposes. All the data was recorded and reported anonymously. The participants were informed that the results would be made available to them after the study was completed.

Data generation was performed in three phases. Firstly, an open-ended questionnaire was completed by 155 students enrolled in an Afrikaans and Dutch module as a first-year module and who are also enrolled for or have completed AGLA111/121. The questionnaire was given to the participants before they had attended any AGLA111/121 classes. Some of the participants $(n=5)$ were second and third-year students who had already completed an AGLA111 or AGLA121 module. Their responses will be treated separately, but are included in the study to see whether students changed their minds and attitudes towards the AGLA111/121 modules over a period of time.

The second phase was conducted three weeks into the academic year after most of the participants had been to AGLA111/121 classes and were more informed about what the module entailed. A focus group interview was conducted with five randomly selected students from a class of an AGLA121 lecturer. The lecturer was not present during the interview to 
provide the participants an opportunity to reveal what they really thought about the module. The participants were reminded to talk about the AGLA121 module and not about the lecturer as it was the module that was being evaluated and not the lecturer, in order to avoid this being a confounding factor. In this way the focus was aimed at the module rather than the lecturer; however, it is not within the researchers' power to ensure that this factor did not have an effect on the respondents.

The last phase was conducted at the end of the semester after the module had been completed. For this phase, 70 randomly selected AGLA111/121 students from various fields in the Faculty of Arts were asked to complete an open-ended questionnaire by writing a paragraph on the following question: Is AGLA111/121 necessary?

\section{FINDINGS AND DISCUSSION}

\section{Phase one}

The responses of the open-ended questionnaire are listed after each question with the original Afrikaans question in brackets. With the responses the original Afrikaans responses are listed first, followed by English translations; language errors in the original responses are displayed in bold as they are not transferred to the English translations. The language errors also illustrate the lack of care shown by the research population when using language.

The first question relates to the TAG test. The TAG test is included in this study as it is the first contact that most students have with academic literacy as a concept at university, and opinions about the module can be formed with the experience of this test. The test is usually written a few days after the students arrive for the first-year orientation programme.

\section{Question 1: How did you experience the TAG test? (Hoe het jy die TAG-toets ervaar?)}

A few participants stated that they enjoyed the test and mentioned that it was relatively easy. One participant indicated that the test had given him/her a better perception of his/her own knowledge and skills and what was expected at university level. The following remark, made by a participant, summarises the gist of most neutral and positive replies toward the test:

Alhoewel daar 'n paar strikvrae was, was die toets oor die algemeen billik. (Although there were some trick questions, generally the test was reasonable.)

Other replies included:

Die TAG-toets was vir my baie moeilik. Ek het baie vrae geraai.

(The TAG test was very difficult for me. I had to guess many of the answers.)

Dit was 'n goeie (tog voel ek nie heeltemal akkurate) wyse om my vaardighede te bepaal.

(It was a good (however, I feel not totally accurate) way to determine my [level of] skills.) 
Dit was nie te moeilik nie. Van die vrae was moeilik om te doen, maar was op goeie standaard.

(It wasn't too difficult. Some of the questions were difficult to do, but was on a good standard.)

However, the majority of the participants felt that the TAG test was a waste of time, was quite difficult or was confusing at times. The participants also indicated that they did not have enough time to complete the test. One participant commented that all that was communicated to them was where and when they had to write the test and that no additional information was provided and that they did not know what to expect from the test. Some participants also stated that they thought they might have done better if they had an example of the test prior to writing the actual test despite the fact that a sample test was available on the university's website. In a study by Van der Walt and Steyn (2008:201) on the same test and in the same context, it was found that participants felt the test was not transparent, too long and they felt they were misinformed about the purpose of the test. Since this publication, therefore, it is clear that little has changed.

Some of the additional comments included:

Die toets was stresvol en jy kon nie heeltyd fokus nie omdat jy weet dit is belangrik. (The test was stressful and you could not focus all the time because you knew that it was important.)

Dit was nie lekker nie, want ek was nie voorberei nie en dit maak my meer stress. (It wasn't nice, because I was not prepared and it made me stress more.)

Another factor that must be considered and which can also have an influence on their results is the fact that almost all of the students noted that they were tired when they wrote the test as first-year orientation programme had already begun. The fact that students were tired when writing the test was also found in a study by Van der Walt and Steyn (2008:202).

\section{Question 2: What did you hear about AGLA from seniors or other students prior to starting with the module? (Wat het jy vooraf by die seniors of ander studente van AGLA gehoor?)}

Research has shown that peers' opinions and attitudes have an influence on students' educational aspirations and motivation for learning (Kandel \& Lesser, 1969:222; Brown, 1994:168; Brunton, 2009:24).

Most of the respondents indicated, according to the seniors and other students, that AGLA111/121 were a waste of time and money and not enjoyable modules to have and that the module had to be completed as soon as possible. Some participants also mentioned that the modules were quite easy to fail if you do not attend all the classes and complete all the assignments. Some of the participants replied positively that if one struggled with language and did not know how to do assignments, the modules were quite valuable in learning how to perform better at university. Some participants also indicated that the modules would have an influence on their other modules as they would get better marks in assignments. Some relevant responses include: 
[dit is] baie irriterend en dat mens dit so gou as moontlik moet afhandel sodat jy op jou 'regte' vakke kan fokus.

([it is] very irritating and that one has to complete it as soon as possible so that you can focus on your 'real' subjects.)

Dat die klasse baie vervelig is. Almal is gewoonlik bly om daarmee klaar te maak.

(That the classes are very boring. Everyone is usually very glad when they are finished with it.)

It became quite clear that the participants were quite annoyed that AGLA111/121 were compulsory modules and stated that the modules wasted valuable time that they would rather have spent on their 'real' and 'important' modules. It was also recorded previously in a similar study that students were 'unhappy about having to do the course' (Van der Walt \& Steyn, 2008:201). One participant made the following remark:

AGLA111 laat my minderwaardig voel. (AGLA111 makes me feel inferior.)

Some students are compelled, according to their scores on the TAG test, to complete both the AGLA111 and AGLA121 modules. In such cases a perception exists that the students who have to complete both modules are weaker academically and consequently they feel inferior.

\section{Question 3: Do you think you need the AGLA modules? (Dink jy dat jy die AGLA-modules nodig het?)}

Some of the participants replied that bridging the gap between school and university was quite difficult and that the modules were indeed necessary to facilitate their adaptation to the new environment. They also mentioned that the modules would help them to function optimally at university standard and that the modules would assist them to improve their reading and writing skills, as the standards at some schools were not on par. Some of the participants also mentioned that the AGLA module would certainly help them in their other modules.

Even though there were a few positive comments, most of the replies were of a negative nature. Quite a few of the participants felt that their high schools had adequately prepared them for university studies and thought that the content of a literacy module would be like high school Afrikaans as subject:

Nee, want die meeste mense ken hulle tale want meeste mense is klaar geletterd. (No, because most people know their languages, because they are already literate.)

Nee, dit is taalkunde en bassiese vaardighede wat ek in vrö̈ё hoërskool geleer het. (No, these are language and basic skills that I learned early in high school.)

Nee, dis mos nie dat almal sukkel met taal gelettertheid.

(No, not everyone struggles with language literacy.) 
It was interesting to note that the above-mentioned last two quotations stated that the participants felt that they did not need the module; however, they could themselves not spell correctly. This shows the discrepancy that exists between what students think they know and are able to do and what they actually know and are able to do.

\section{Question 4: Are you enthusiastic about AGLA? Why/why not? (Is jy entoesiasties oor} AGLA? Hoekom/hoekom nie?)

Overall, most of the participants were not extremely enthusiastic about the modules initially; yet, they realised that it was important to be enrolled for the module and that the AGLA modules could help them develop the literacy skills required at university and could help with assignments in their other modules and even one day with their chosen careers. Mostly, however, the participants mentioned that they were quite severely influenced by the senior students and were not too keen on having to be enrolled in the AGLA modules. The participants also complained that some of them have a very busy schedule and wanted to spend more time on their other studies.

Two of the participants (who had already completed the module) made the following comments:

Ek was eers nie entoestiasties oor AGLA nie omdat die senior studente gesê het dat dit moeilik was maar toe ek eers die vak doen was dit glad nie wat ek gedink het nie en het dit my baie gehelp.

(At first I wasn't enthusiastic about AGLA, because senior students said that it is difficult. However, once I started with the subject I realised that it wasn't what I thought it would be and it helped me a great deal.)

Een het vir my gesê dit is soos grad 11 Afrikaans. Nou na ek dit afgehandel het, het ek ook my opini verander en sien ek die doel.

(One person told me that it was like grade 11 Afrikaans. After I had finished it, I changed my opinion and I can see the purpose of it.)

A clear pattern is evident from the data as, at first, most students are extremely negative about the module, but afterwards they realise its value.

Question 5: Are you planning to attend all your AGLA classes? Why/why not? (Is jy van plan om al jou AGLA-klasse by te woon? Hoekom/hoekom nie?)

The minority of the respondents stated that they were excited about the module. Most responses were quite neutral, as the participants stated that they did not really want to attend the modules' classes but that their parents expected them to pass all their modules as not to waste their money. However, quite a few stated that they were considering not attending all the classes, as they really did not want to do the module. Some responses include:

Ja, ek sal net myself benadeel deur nie te gaan nie.

(Yes, I will only disadvantage myself by not going.) 
Oor die algemeen is ek nie baie entoesiasiteis daaroor nie, maar ek weet tog dat dit 'n belangrike vak is.

(In general, I am not very enthusiastic about it, but I do know that it is an important subject.)

To supplement the data acquired from the questionnaires, a focus group interview was held with participants from another group of students.

\section{Phase two}

In this section the transcribed comments from the focus group interview held with the students who were already exposed to the module will be discussed. The questions were exactly the same as in phase one.

\section{Question 1: How did you experience the TAG test? (Hoe het jy die TAG-toets ervaar?)}

The following response from the focus group interview refers to the circumstances around the first-year orientation programme.

Dit was nie 'n te moeilike toets nie, maar ons koshuismense...Tydens $O$ en $B$-jy kan nie fokus nie, jou brein is dik en jy is moeg want jy het niks geslaap nie en nou moet jy 'n toets skryf wat eintlik belangrik is. Ek dink daar sit heel waarskynlik mense in AGLA111 wat nie daar moet wees nie omdat hulle swak gedoen het in 'n toets omdat hulle moeg was.

(It wasn't such a difficult test, but we who live in the hostel... You cannot focus during the first-year orientation programme as your mind feels clouded and you are tired as you have not slept and now you have to write a test that is actually quite important. I am sure there are many people enrolled in AGLA111 who should not be there because they only did badly in the test because they were tired.)

Weideman (2006:82-83) claims that the TAG test is a low to medium-stakes test; however, for many students taking a module that they do not necessarily need and the financial implications of an additional module are, according to the researchers, a high-stakes issue with high-stakes implications. The participants also all agreed that they did not have enough time to complete the test.

Question 2: What did you hear about AGLA from seniors or other students prior to starting with the module? (Wat het jy vooraf by die seniors of ander studente van AGLA gehoor?)

Nog 'n aanmerking wat mens nogal gereeld hoor is dat dit 'n geldmaakstorie is. (Another comment that you hear quite often is that it is a moneymaking scheme.)

The participants from the focus group voiced almost exactly the same responses regarding the module: that the module is a waste of time and that they had busy schedules and would rather focus on their 'real' modules. The fact that the module seems to be a moneymaking scheme can also have a negative impact on how the module is perceived by future students. 


\section{Question 3: Do you think you need the AGLA modules? (Dink jy dat jy die AGLA-modules} nodig het?)

The only participant from the group who had to repeat the module, made the following comments:

'Nee, veral die hele lees ding, hulle sê dit is om jou spoed te verbeter, maar ek dink nie my spoed het enigsins verbeter nie.'

(No, especially the reading thing, they say that it is supposed to improve your reading speed, but I do not think that my reading speed improved at all.)

'Nee, want dit mors my tyd. Die onderwerpe wat ons verlede jaar gekry het was hoegenaamd nie van toepassing op my studierigting nie.'

(No, because it wastes time. The topics we received last year were not related to our fields of study at all.)

The second comment is quite relevant as it touches upon the contentious subject of the 'commoncore' versus 'subject-specific' issue in language pedagogy that has been debated for at least twenty years' (Carstens \& Fletcher, 2009:319). Students want to see the application value of their other modules.

The only participant from the group who was positive about the module provided the following insights:

'Ek hou tans van die vak en ek sien uit daarna om te leer hoe om reg te skryf op universiteit. Mense moet regtig ophou kla oor die vak. Ja, dit is moeilik om dit saam met al jou ander vakke te doen, maar dit kan jou net help!'

(I currently like the subject and I am looking forward to learning how to write correctly at university. People should really stop complaining about the subject, Yes, it is difficult to do it with your other subjects, but it can just help you!)

\section{Question 4: Are you enthusiastic about AGLA? Why/why not? (Is jy entoesiasties oor AGLA? Hoekom/hoekom nie?)}

Most of the participants in the group were not at all enthusiastic about the module and echoed the replies made in phase one. According to them, the module is a waste of time and takes away a great deal of their time that could have been spent on other modules. One participant stated that she could understand why some of the weaker students had to take the module, but that she received $95 \%$ for the school subject Afrikaans Home Language in her grade 12 final examination and felt that she knew how to write (except for referencing and compiling a bibliography). Another participant concurred and stated that they were adequately prepared in their language classes for university.

Question 5: Are you planning to attend all your AGLA classes? Why/why not? (Is jy van plan om al jou AGLA-klasse by te woon? Hoekom/hoekom nie?) 
When asked whether they were planning on attending all the module's classes, two participants indicated that they would come to class. One of the two participants explained that she did not want to attend classes, but that she could not afford to fail a module and therefore had to attend. The other three participants said outright that they were not planning on attending all of the classes - only the ones scheduled for assessments.

The final phase of the empirical research was conducted with a group of students who had completed the academic literacy module. This group was chosen in order to gauge the attitude of participants after completing the module.

\section{Phase three}

The last phase was conducted at the end of the semester after the module had been completed. Some of the responses showed evidence of a common theme repeated by the respondents.

- One might feel that it is unnecessary, because you already had Afrikaans as a subject for twelve years and some passed it with a distinction. Maybe they can change the rules to apply only to those who did not get a distinction in Afrikaans in matric.

- Many people agree that AGLA is a waste of time

- AGLA is a very irritating subject for many students.

- A subject with a reputation of being an unnecessary addition to an already busy semester.

- Most students say that AGLA is unnecessary to have at university, because they feel that they studied the work of this subject when they were in school

The responses also included some positive elements:

- ...but without it we would not be able to do some critical aspects in writing

- Many people think it is a waste of time but they are wrong.

- This subject will appear more useful in the future when it saves you from a bad grade

- Most people do not realise why this is of such importance, but the reason why this subject is added to the curriculum is to prevent serious problems such as plagiarism

- I strongly disagree with them. AGLA improves your writing skills. With these new skills that you learn in AGLA you can look more professional in your work in the future.

- It is a necessary subject because without it, students might fail quite a few subjects.

In general, it is clear that the students are influenced initially by their peers; however, when they have completed the module, they tend to appreciate the value of the module.

\section{CONCLUSION}

As mentioned in the introduction, it is a well-known fact that students' literacy levels are not up to standard. However, managers at universities, course designers, lecturers and peers (as more knowledgeable others), must also take on some of the responsibilities to make the transition for first-year students as smooth and stress-free as possible. 
Therefore, at the NWU, a compulsory academic literacy module (AGLA111/121) is provided to all first-year students to assist them in making the transition from high school to university and to help students cope with the university's and their faculties' literacy requirements.

A qualitative evaluation was done on the module to determine how the first-year students' emotions, attitudes and perceptions have an influence on their motivation to complete the module and ultimately learn the required skills to become academically literate. From the empirical research, some of the successes and shortcomings of the module were highlighted and reflected through the participants' thoughts and feelings about the module.

Possible solutions to address some of the issues identified by the participants are suggested:

- There must be more transparency regarding the TAG/TALL test and students must have easier access to examples of the test way in advance so that they feel more prepared and in control.

- The test must be administered before the students start with first-year orientation so that they are not as tired when they have to complete the test.

- Much more active marketing about the reasons for and the value of the module as well as literacy statistics must be communicated to the students so that they could realise why they have to complete the module.

- Regarding the content of the module, the course designers should revisit the debate regarding academic literacy courses vs. subject-specific courses. If the content of the module is more related to their study fields, and is more authentic and meaningful, the profile of the module might be raised to being a 'proper' module in the eyes of the students.

- If students do not see the relevance of the module and are not enthusiastic about the module, the effect is evident. They will not attend the classes, will not learn the required skills, will not pass the module and will feel angry and upset about the module. Therefore, if the affective variables are not taken seriously, all the issues raised by the participants will be cyclical in nature as future students stand to be influenced before they even set foot on a university campus.

We do not intend to claim that students' literacy skills will miraculously improve by bringing emotions into the equation. However, as affective variables do have an effect on learning and eventually the possible acquisition of academic literacy skills, they do need to be taken seriously within the teaching and learning context and their effect on learning must be explored further.

\section{ENDNOTES}

1. Massification refers to the fact that universities are no longer reserved for and the prerogative of the elite and privileged, but for all the masses that want to attend (Holder et al., 2006:19; Henderson \& Hirst, 2006:3; Teichler, 1998:19; Boli, Ramirez \& Meyer, 1985:145). 


\section{REFERENCES}

BROWN HD. 1994. Principles of Language Learning and Teaching. Englewood Cliffs. NJ: Prentice Hall.

BRUNER, J. 1990. Acts of meaning. Cambridge, MA: Harvard University Press.

BRUNTON, MWC. 2009. An evaluation of students' attitudes to the general English and specific components of their course: a case study of hotel employees in Chang Mai, Thailand. ESP world, 25(4):1-82.

CARSTENS, A \& L FLETCHER. 2009. Quantitative evaluation of a subject-specific essay intervention. Southern African Linguistics and Applied Language Studies, 27(3):319332.

COLES, G. 1999. Literacy, Emotions and the Brain. Available: http://www.readingonline.org/critical/coles.html.

CROUCH, A. 2006. Teaching academic writing in a South African context: an evaluation of the drafting-responding process used to develop the academic writing of students in a first year Media course at the University of KwaZulu-Natal. Unpublished MA Thesis. University of KwaZulu-Natal, Durban.

DEHBOZORGI, E. 2012. Effects of attitude towards language learning and risk-taking on EFL students' proficiency. International Journal of English Linguistics, 2(2):41-48.

DÖRNYEI, Z \& E USHIODA. 2010. Teaching and Researching Motivation. Harlow, Pearson.

DRACKLE, D. 2006. Comments on Brian Street's paper: "Autonomous and Ideological Models of Literacy: Approaches from New Literacy Studies". E-Seminar January 17-24. 2006, European Association of Social Anthropologists (EASA), Media Anthropology Network. Available: http://www.media-anthropology.net/drackle_comment.pdf [27 February 2013].

GARDNER, RC. 1985. Social psychology and second language learning: the role of attitudes and motivation. London: Edward Arnold.

GARDNER, CR \& EW LAMBERT. 1972. Attitudes and Motivation in Second-Language Learning. Rowley, MA: Newbury House.

GEE, JP. 1989. Literacy, Discourse, and Linguistics: an introduction. Journal of Education, 171(1):5-17.

HARLEN, W. \& RD CRICK. 2003. Testing and Motivation for Learning. Assessment in Education. 10 (2) 169-207.

HOLDER, GM, J JONES, RA ROBINSON. \& I KRASS. (1999). Academic Literacy Skills and Progression Rates Amongst Pharmacy Students. Higher Education Research and Development 18 (1),19-30.

HU, H, E REAL, K TAKAMIYA, M KANG, J LEDOUX, RL HUGANIR, \& R MALINOW. 2007. Emotion Enhances Learning via Norepinephrine Regulation of AMPA-Receptor Trafficking. Cell, 131:160-173.

HUGO, A. 2003. From literacy to literacies: preparing higher education in South Africa for the future. South African Journal for Higher Education, 17 (2):46-53. 
ICELDA. Inter-institutional Centre for Language Development and Assessment Home. 2013. Available: http://icelda.sun.ac.za/.

INAL, S, I EVIN \& AS SARACALOGLU. 2005. The relation between students' attitudes toward foreign language achievement. Dil Dergisi, 130:38-52.

KANDEL, DB \& GS LESSER. 1969. Parental and peer influences on educational plans of adolescents. American sociological review, 34(2):213-223.

KELDER, R. 1996. Rethinking literacy studies: from the past to the present. Available:

http://www.literacy.org/sites/literacy.org/files/publications/kelder_review_of_lit_studies_96.p df.

KELLER, J. 1983. Motivational design of instruction. In Reigeluth, C.M. (ed), Instructional Design Theories and Models: An overview of their current status. Hillsdale, NJ: Lawrence Erlbaum Associates. 383-434.

KILLEN, R. 2000. Teaching strategies for outcomes-based education. Lansdowne: Juta.

KRASHEN, S. 1981. Second language acquisition and second language learning. London: Pergamon.

MASGORET, A-M \& RC GARDNER. 2003. Attitudes, motivation, and second language learning: a meta-analysis of studies conducted by Gardner and associates. Language Learning, 53:123-163.

NOELS, KA, LG PELLETIER \& RJ VALLERAND. 2000. Why are you learning a second language? Motivational orientation and self-determination theory. Language Learning, 50:57-85.

PEKRUN, R, T GOETZ, W TITZ \& RP PERRY. 2002. Academic Emotions in Students' Self-Regulated Learning and Achievement: A Program of Qualitative and Quantitative Research. Educational Psychologist, 37(2):91-105.

PICARD, MY. 2006. Academic literacy right from the start: a critical realist study of the way university literacy is constructed at a Gulf university. Unpublished Doctoral Dissertation. Rhodes University, Grahamstown.

PICKENS, J. 2005. Attitudes and perceptions. In Borkowski, N (ed), Organizational behaviour in Health Care. London: Jones and Bartlett Publishers. 43-76.

RICHTER-LEVIN, G \& I AKIRAV. 2003. Emotional tagging of memory formation - in the search for neural mechanisms. Brain Research Reviews, 43:247-256.

RUBIN, J \& I THOMPSON. 1994. How to be a more successful language learner. Boston, MA: Heinle \& Heinle.

SKILLEN, J. 2006. Teaching academic writing from the 'centre' in Australian Universities. In Ganobcsik-Williams, L (ed), Teaching academic writing in UK higher education: theories, practices and models. Houndmills: Palgrave Macmillan. 140-151.

STREET, BV. 1984. Literacy in theory and practice. Cambridge: Cambridge University Press.

STREET, BV. 2003. What's "new" in New Literacy Studies? Critical approaches to literacy in theory and practice". Current issues in comparative education, 5(2): 77-91. 
TOWNSEND, R. 2010. The national curriculum statement on writing practice design for grades 11 and 12: implications for academic writing in higher education. Unpublished MA dissertation. Nelson Mandela Metropolitan University, Port Elizabeth.

VAN DER WALT, JL \& F STEYN. 2008. The validation of language tests. Stellenbosch Papers in Linguistics, 38:191-204.

VAN DYK, TJ. 2005. Towards providing effective academic literacy intervention. Per Linguam, 21(2):38-51.

VAN SCHALKWYK, SC. 2008. Acquiring academic literacy: a case of first-year extended degree programme students at Stellenbosch University. Unpublished Doctoral Dissertation. University of Stellenbosch.

VAN SCHALKWYK, S. 2010. When the teacher becomes the student: the acquisition of academic literacy revisited. Acta Academica Supplementum, (1):201-222.

VYGOTSKY, LS. 1978. Mind in society: The development of higher psychological processes. Cambridge, MA: Harvard University Press.

VYGOTSKY, LS. 1987. The collected works of L.S. Vygotsky. New York: Plenum.

WEIDEMAN, A. 2006. Assessing academic literacy: a task-based approach. Language Matters, 37(1):81-101.

WEIDEMAN, A. 2007. Academic literacy: prepare to learn. Pretoria: Van Schaik.

\section{BIOGRAPHICAL NOTES}

Louise Olivier is a lecturer in academic literacy at the Centre for Academic and Professional Language Practice of the North-West University (Potchefstroom campus). She is completing a PhD on academic literacy and her research focus is on academic writing for nursing students.

E-mail address: Louise.Olivier@nwu.ac.za

Jako Olivier is a senior lecturer in Afrikaans linguistics at the School of Languages of the North-West University (Potchefstroom campus). His research interests include accommodating multilingualism in education through blended learning, language planning, Afrikaans language variation and academic writing.

E-mail address: Jako.Olivier@nwu.ac.za 